\title{
GROUP MEETING
}

\section{Contemporary Religious Literature Conversation Group}

Facilitators

Donna Wells, Southeastern Baptist Theological Seminary Jennifer Ulrich, Eastern Mennonite University

\begin{abstract}
The Contemporary Religious Literature Conversation Group provides a space during the annual conference to discuss books and other resources that the group finds interesting and meaningful. It's a good place to find the next book on your reading list.
\end{abstract}

A small group met on Friday morning to discuss what they have been reading throughout the year.

The group discussed Nancy Pearl's “Rule of 50,"1 which basically says, read fifty pages of a book and then if you don't like it go ahead and move on to the next book. We decided that it is okay to put down a book if you don't like it.

We had a good time chatting about what we'd been reading and watching. Here's the list.

Berry, Steve. The Malta Exchange. New York: Minotaur Books, 2019.

Card, Orson Scott. Rachel \& Leah: Women of Genesis. New York: Forge, 2005.

Card, Orson Scott. Rebekah: Women OfGenesis. New York: Tom Doherty Associates, 2001. 
Card, Orson Scott. Sarah: Women of Genesis. New York: Forge, 2001.

Cosper, Mike. Faith among the Faithless: Learning from Esther How to Live in a World Gone Mad. Nashville, Tennessee: Nelson Books, an imprint of Thomas Nelson, 2018.

Hastings, Max. Winston's War: Churchill, 1940-1945. New York: Vintage Books, 2011.

Haog, G. G., W. K. Willmer, and G. H. Henson. The Council: A Biblical Perspective on Board Governance: ECFAPress, 2019.

McDermott, Alice. The Ninth Hour. London: Bloomsbury Publishing, 2018.

Millard, Candice. Hero of the Empire: the Boer War, a Daring Escape, and the Making of Winston Churchill. New York: Anchor Books, 2017.

Miller, Madeline. Circe. London: Bloomsbury Publishing, 2019.

Sanneh, Lamin O. Translating the Message: The Missionary Impact on Culture. Maryknoll, N.Y.: Orbis Books, 2009.

Shteyngart, Gary. Super Sad True Love Story. London: Granta, 2010.

Vodolazkin, E. G. and Lisa C. Hayden. Laurus. London: Oneworld Publications, 2016.

Westover, Tara. Educated: A Memoir. New York: Random House, 2018.

Wilson-Lee, Edward. The Catalogue of Shipwrecked Books: Young Columbus and the Quest for a Universal Library. London: William Collins, 2018.

Wright, Joe (dir.), Tim Bevan, Eric Fellner, Lisa Bruce, Anthony McCarten, Douglas Urbanski, Gary Oldman, et al. Darkest Hour. Universal City, CA: Universal Studios, 2018.

\section{ENDNOTES}

1 “Nancy Pearl's Rule of 50," Globe \& Mail (Toronto, Canada), https://www.theglobeandmail.com/arts/books-and-media/ nancy-pearls-rule-of-50-for-dropping-a-bad-book/ article565170/. 